\title{
Bail-inable securities and financial contracting: can contracts discipline bankers?
}

\author{
Edoardo MARTINO*
}

\section{INTRODUCTION}

Corporate governance failures and excessive risk-taking have often been blamed as two major drivers of the latest financial crisis. ${ }^{1}$ These failures are ultimately rooted in the existing trade-off between financial stability policies and moral hazard. ${ }^{2}$ The easiest exemplification of such a trade-off is the implicit guarantee of the State on the solvency of financial institutions, especially the "systemically relevant" ones, leading creditors not to exert appropriate monitoring, and softening the budget constraints of bank managers.

The financial crisis hit EU Member States particularly hard, and the existing regulatory framework was unprepared to face it. The EU has answered with a massive wave of reforms leading up to the European Banking Union, which was welcomed by Commissioner Barnier as "nothing less than a revolution: the most ambitious project since the creation of the euro". ${ }^{3}$ The recovery and resolution framework ${ }^{4}$ represents one of the pillars of the Banking Union, providing EU-wide uniform rules for the recovery and resolution of distressed banks. ${ }^{5}$ Among the tools provided by the Directive, the bail-in tool has drawn substantial policy and academic attention as a regulatory innovation having the potential to disrupt the discourse on financial stability. A bank bail-in consists in the power

\footnotetext{
* Ph D Researcher in Law \& Economics at Erasmus University Rotterdam, School of Law; Member of the Young Researcher Group of the European Banking Institute (EBI); Visiting Researcher at University of Amsterdam, Amsterdam Centre for Law and Economics. Emails martino@law.eur.nl, e.d.martino@uva.nl. My deepest gratitude goes to Emilios Avgouleas, Christos Hadjiemmanuiland, Klaus Hopt, Luis Silva Morais, Alessio Pacces, Georg Ringe, Renè Smits and Lorenzo Stanghellini for their priceless feedback and insights. Thanks to Elena Ghibellini, Titian Kejer, Katarzyna Parchimowicz, Francesco Pennesi and Ross Spence for their comments on earlier versions of the manuscript. An earlier version of the paper was presented at the "Erasmus Early-Career Scholars Conference" in Rotterdam; "Building the Banking Union: the challenges ahead" in Lisbon; the "EDLE Workshop" in Bologna and the "14 "Annual Conference of the Italian Society of Law and Economics". Helpful comments of participants are gratefully acknowledged. Finally, my gratitude goes to the anonymous referee for his comments and appreciation. All remaining errors are mine.

1 See J De Larosière et al, "Report of the High-Level Group on Financial Supervision in the EU” (Brussels, European Commission 2009) para 23.

2 See WA Allen and G Wood, "Defining and Achieving Financial Stability" (2006) 2 Journal of Financial Stability 152 at 160.

3 Speech at the Peterson Institute for International Economics, Washington, 13 June 2014.

4 This paper will focus on the Bank Recovery and Resolution Directive (BBRD), Directive 2014/59/EU of the European Parliament and of the Council of 15 May 2014 establishing a framework for the recovery and resolution of credit institutions and investment firms [2014] OJ L 173.

5 Substantive legislation binds all Member States, while procedural and institutional arrangements are harmonised only at Eurozone level.
} 
of the resolution authority to impose losses of failing banks on both shareholders and creditors through write down or conversion, carried out in an administrative procedure. ${ }^{6}$

Some commentators focused on the alleged ex ante benefits of the bail-in tool. They claim that, once the implicit guarantee of the State is voided, investors sill exert better monitoring, disciplining the hazardous behaviour of the management. Moreover, banks are required to hold in their balance sheets an adequate amount of bail-in eligible liabilities, to assure that, in case of distress, the resolution authority can efficiently perform a bail-in. ${ }^{7}$

Yet, many shades have been cast on both the efficiency and effectiveness of the new regime. $^{8}$ Since a general assessment of the bail-in tool falls outside the scope of this contribution, the paper analyses potential consequences of the new resolution regime on the risk-taking incentives of banks and the role of bail-inable creditors, ie on the moral hazard problem. The role of creditors in disciplining the risk appetite of banks results from the interplay of the governance and financial structure of the bank, where the latter is a function of regulatory constraints. Specifically, this contribution discusses financial contracting as a potential channel to discipline bankers. In other words, the paper aims to answer the following question: given the regulatory framework, can privatesolutions (ie contracts) provide adequate incentives toward optimal risk-taking? Answering such a question allows us to further the understanding of the relationships between regulation of financial structure and corporate governance of banks as well as the governance consequences of the BRRD. As I will show, debt contracts of bail-inable securities are generally unable to discipline bank risk-taking because of peculiarities of bank activities that restrain debt contract from performing as well as in the non-financial industries. Nonetheless, the paper will argue that specific contractual arrangements imposed on a new type of hybrid debt (contingent convertible) can enhance discipline both before and after the event of a bail-in.

The contribution takes an interdisciplinary approach, embracing elements of both banking law and corporate governance. In building a suitable analytical framework, Section II draws insights from the corporate finance theory of debt, mostly focusing on agency and incomplete contract theory, as well as from the economic theory of bank regulation. Grounded on the theoretical foundation of Section II, Section III approaches the qualitative requirements imposed on bail-inable liabilities as constraints to contractual freedom and discusses whether and to what extent creditors can employ contractual devices to discipline bankers. Section IV devotes particular attention to the case for contingent capital, ie liabilities whose design is to absorb losses at a contractually predetermined trigger event, particularly focusing on the governance feature that parties can contract upon. Again, contingent convertible items have been labelled as potentially disruptive instruments in achieving safe and sound banks so that the promises and perils of

\footnotetext{
6 K-P Wojcik, "Bail-in in the Banking Union" (2016) 53 Common Market Law Review 91 at 95.

7 Minimum Requirement for Own Fund and Eligible Liabilities (MREL): Art 45 BRRD. Hence, also regulation on quantitative and qualitative requirements for regulatory capital will be considered.

8 Regarding efficiency, see C Goodhart and E Avgouleas, "A Critical Evaluation of Bail-in as a Bank Recapitalisation Mechanism" in Douglas Evanoff et al (eds), The New International Financial System: Analyzing the Cumulative Impact of Regulatory Reform (World Scientific 2015). Regarding effectiveness, see TH Tröger, "Too Complex to Work: A Critical Assessment of the Bail-in Tool under the European Bank Recovery and Resolution Regime" (2018) 4(1) Journal of Financial Regulation 35. Note, also, that the resolution objectives listed in Art 31 BRRD do not take into account any ex ante benefit.
} 
these items have been widely discussed, mostly by economists, on both sides of the Atlantic. ${ }^{9}$ Their governance impact, on the other hand, is (to the best of the author's knowledge) notably under-studied, especially in Europe. ${ }^{10}$ Section V concludes.

\section{INCOMPLETE CONTRACTS AND BAIL-INABLE SECURITIES}

As outlined in the introduction, this contribution aims to investigate the relationship between the financial and governance structure of banks in the new regulatory framework. A plain legal analysis of the post-crisis reforms appears unsuitable for our purposes. Hence, insights from corporate finance literature, as well as the theory of bank regulation, represent necessary building blocks to provide a sound framework for the analysis.

\section{A theory of debt}

The role of debt and debt contracts has been one of the focal points in corporate finance. Thus, going through the main theoretical explanations of debts and the role of financial contracting is crucial for understanding the role of new bail-inable instruments.

Corporate finance scholars firstly approached the debt from the perspective of the firm, investigating its optimal capital structure (ie which combination of equity and debt financing maximises the value of the firm). Modigliani and Miller ${ }^{11}$ demonstrated that, under a certain set of assumptions, ${ }^{12}$ the choice between equity and debt do not affect the overall value of the firm (the irrelevance proposition). ${ }^{13}$ This basic yet revolutionary idea has been refined, questioning its assumptions. For our interests here, the refinements related to agency and incomplete contract theory are discussed. In fact, agency theory, among other features, explains the fundamentals of the role of debt-holders in the corporation, while incomplete contract theory takes a step forward, explaining why people decide to lend money, and the crucial role that contracts have on that decision.

Jensen and Meckling, relaxing the assumption of symmetric information, showed that the risk (and costs) of bankruptcy are partly shifted from shareholders to bondholders (risk-shift). Therefore, being shareholders in charge, risk-taking tends to be excessive since they bear only a small fraction of the expected bankruptcy costs. " "Gambling for resurrection" incentives represent the extreme consequence of this phenomenon: once financial distress approaches, shareholders are rationally prone to undertake negative net

\footnotetext{
9 For a comprehensive survey, see M Flannery, "Contingent Capital Instruments for Large Financial Institutions: A Review of the Literature” (2014) 6 Annual Review of Financial Economics 225.

10 In the US some attention has been devoted to the topic, see J CoffeeJr, "Systemic Risk after Dodd-Frank: Contingent Capital and the Need for Regulatory Strategies beyond Oversight” (2011) 111 Columbia Law Review 795. But the policy recommendation by Coffee would be unavailable according to the EU regulatory framework.

11 F Modigliani and M Miller, "The Cost of Capital, Corporation Finance and the Theory of Investment" (1958) 48 The American Economic Review 261.

12 Absence of bankruptcy costs, symmetric information and absence of taxes.

13 This approach represents the theoretical background for recent proposals for sharply increasing regulatory capital of banks. See A Admati and M Hellwig, The Bankers' New Clothes: What's Wrong with Banking and What to Do about It (Princeton University Press 2014).

14 This issue is amplified in banking, given its inherently highly levered nature. The fraction of bankruptcy costs borne by shareholders is smaller and incentives towards risk-taking increase. This represents a standard argument for capital regulation, as explained in the remainder of the section: see J Armour et al, Principle of Financial Regulation (Oxford University Press 2016) ch 16.
} 
present value projects, yielding high returns with low probabilities, since they would fully gain the benefits without bearing any costs. ${ }^{15}$

Building on agency theory, the "costly contracting hypothesis"16 of debt argues that controlling the bondholder-shareholder conflicts can increase the value of the firm. In other words, creditors can play a positive role in the governance of the firm. In fact, although financial contracting is costly, parties are willing to bear these costs (eg draft a covenant) as long as the benefits deriving from financial contracting outweigh the bargaining and enforcement costs, at the margin.

The literature analysed so far explains the role of debt for the value of the firm, but fails to expain why people are willing to lend and become creditors. This link is crucial, as corporate governance has been defined as the ways in which suppliers of finance (including creditors) to corporations assure themselves of getting a return on their investment. ${ }^{17}$

In the understanding of how creditors assure themselves of getting a return on their investment, the introduction of contract incompleteness signalled a groundbreaking change. ${ }^{18}$ Aghion and Bolton modelled debt contracts as a mechanism to allocate control, contingent on future situations that are difficult or impossible to describe ex ante. ${ }^{19}$ Accordingly, the capital structure of a firm is relevant for managerial incentives as long as contracts are incomplete, ie their enforcement is constrained by the lack of compelling provisions for each and every possible course of action.

Contingent allocation of control evokes, first and foremost, statutory bankruptcy, where the ability of the shareholders to retain control is contingent on meeting the debt obligation. Apart from that, one can think of debt covenants restricting the courses of action available to the firm and thus limiting the control power of shareholders. ${ }^{20}$ Again, secured debt can be seen as a way of allocating control over specific assets to a creditor, contingent on default of a contractual obligation.

\section{Bank debt and its peculiarities}

In the specific context of banks, the understanding of contingent allocation of control needs to be broadened, since debt is excessively difficult to restructure ${ }^{21}$ so that short-

\footnotetext{
15 For a simple numerical example, see M Becht et al, "Why Bank Governance Is Different" (2011) 27 Oxford Review of Economics and Politics 437 at 459.

16 Such hypothesis builds mainly on S Myers, "Determinants of Corporate Borrowing" (1977) 5 Journal of Financial Economics 147; C SmithJr and J Warner, "On Financial Contracting: An Analysis of Bond Covenants" (1979) 7 Journal of Financial Economics 117.

17 A Shleifer and R Vishny, “A Survey of Corporate Governance” (1997) 52 The Journal of Finance 737.

18 SJ Grossman and OD Hart, "The Costs and Benefits of Ownership: A Theory of Vertical and Lateral Integration" (1986) 94(4) Journal of Political Economy 691.

19 P Aghion and P Bolton, "An Incomplete Contracts Approach to Financial Contracting" (1992) 59 Review of Economic Studies 473 .

20 For a complete taxonomy of covenants, see M Bradley and M Roberts, "The Structure and Pricing of Corporate Debt Covenants" (2015) 5(2) Quarterly Journal of Finance.

21 P Bolton and O Jeanne, "Structuring and Restructuring Sovereign Debt: The Role of a Bankruptcy Regime" (2007) 115 Journal of Political Economy 901.
} 
term debt can also be seen as a way of allocating control. ${ }^{22}$ In fact, given the impossibility of designing long-term contracts ex ante, parties agree on short-term exposures with a view to rolling them over as long as the firm's situation does not deteriorate. $^{23}$

Considering this peculiarity, one could also wonder whether, and to what extent, such a theory of debt applies to banks. In fact, banks are acknowledged to be, somehow, "special" for a wide array of reasons, among which at least two are crucial here. $^{24}$

First, banks perform a maturity transformation of their assets, as they borrow money short term and lend long term, exposing banks to (retail and wholesale) run. ${ }^{25}$ This provides a sound argument for deposit guarantee which, in turn, begs for intrusive regulation substituting for the lack of monitoring. ${ }^{26}$ As a by-product, banks implicitly rely on public bailouts, strengthening the moral hazard problem.

Second, large and interconnected banks generate systemic risk, meaning that the failure of a financial institution results in much bigger costs than the ones borne by the institution, as the effects of one failure propagate to the rest of the financial system (eg contagion risk, trust issues, etc). ${ }^{27}$

The post-crisis wave of reforms has confronted both of these issues, introducing the concept of loss of absorbency capacity of banks' liabilities, ie banks should bear in their balance-sheets sufficient instruments to be internally recapitalised if in trouble, minimising the impact on financial stability. ${ }^{28}$ Those instruments can be either capital, as defined by the Basel III accords, ${ }^{29}$ or non-capital instruments that are apt to absorb losses. ${ }^{30}$ What makes an instrument apt to absorb losses are its qualitative characteristics, ie its contractual arrangements.

In the EU, the regulatory framework for loss-absorbing instruments is composed by the Capital Requirement Regulation (CRR), ${ }^{31}$ laying down qualitative and quantitative requirements for capital instruments; and the BRRD, dealing with the qualitative requirements for non-capital instruments that are considered "eligible" to be counted as bail-inable liabilities. ${ }^{32}$ Once the bank goes into financial distress and becomes "failing

\footnotetext{
22 Technically: an inefficient equilibrium derived by the impossibility of differently allocation control: see D Diamond and R Rajan, "A Theory of Bank Capital” (2000) 55 The Journal of Finance 2431.

23 On the relevance of short-term contract in bank financing, see Mark J Flannery, "Debt Maturity and the Deadweight Cost of Leverage: Optimally Financing Banking Firms" (1994) 84 The American Economic Review 320.

24 For a comprehensive explanation, see M Brunnermeier et al, The Fundamental Principles of Financial Regulation, vol 11 (ICMB 2009).

25 D Diamond and P Dybvig, "Bank Runs, Deposit Insurance, and Liquidity" (1983) 91 Journal of Political Economy 401 .

26 The so-called "representation hypothesis", as proposed by M Dewatripont and J Tirole, The Prudential Regulation of Banks (MIT Press 1994).

27 On systemic risk see extensively, S Schwarcz, "Systemic Risk" (2008) 97 Georgetown Law Journal 193.

28 FSB, "Key Attributes of Effective Resolution Regimes for Financial Institutions" (2011).

29 BCBS, Basel III: A Global Regulatory Framework for More Resilient Banks and Banking systems (2010).

30 See FSB, "Principles on Loss-Absorbing and Recapitalisation Capacity of G-SIBs in Resolution - Total Loss Absorbency Capacity" (2011).

31 Regulation (EU) No 575/2013 of the European Parliament and of the Council of 26 June 2013 on prudential requirements for credit institutions and investment firms [2015] OJ L 176.

32 Quantitative requirements for bail-inable securities are not set down in primary legislation, but are individually determined by the resolution authority together with the supervisory authority, pursuing Art 45(6) BRRD.
} 
or likely to fail", ${ }^{33}$ the resolution authority can decide to write-down or convert bail-in eligible claims through the so-called bail-in mechanism, recapitalising the bank without the need for a State bailout. ${ }^{34}$

Therefore, from an ex ante perspective, loss-absorbing instruments are designed to work as a self-insurance buffer against the risk of financial distress, insofar as the losses arising from financial distress are allocated to investors in bail-inable securities and not to the general public. In a world of complete contracts, ${ }^{35}$ this should also optimise the risk-taking incentives of bankers, since each future course of action would be governed in a manner that is consistent with the fulfilment of the contractual obligations attached to bail-inable securities, ie not becoming "failing or likely to fail" so to avoid losses for bailinable debt-holders. ${ }^{36}$

Nonetheless, in a world of incomplete contracts such an outcome is dubious, bearing in mind that qualitative requirements on loss-absorbing instruments and the administrative discretion of the resolution authority further constrain the possibility of efficiently allocating control. This paper, therefore, discusses the qualitative requirements for bail-in eligible liabilities from the perspective of the investor, ie as a set of constraints on contractual possibilities.

\section{CONTRACTUAL FREEDOM AND REGUlATORY CONSTRAINTS}

The qualitative requirements of bail-inable instruments ensure that, in the event of financial distress, the bank can absorb losses, according to the seniority of its liabilities: the more junior a liability is, the stricter requirements are. Hence, the primary objective of qualitative requirements is to preserve financial stability and minimise the need for public bailouts.

From the perspective of an investor, strict qualitative requirements mean constraints on the ability to bargain on the terms of the investment. This implies, in turn, limited chances for contractual solutions to efficiently allocate contingent control. Consequently, investors will rely more and more on the roles of regulators and supervisors $^{37}$ in disciplining the manager's behaviour. The discretion of the resolution authority in imposing losses in the event of distress additionally hampers the condition of investors in bail-inable securities, resulting in a large degree of uncertainty about the return on their investments. ${ }^{38}$

This section outlines the qualitative requirements of capital and non-capital bail-inable securities (see section 1 below). The compliance of control allocation mechanisms with such requirements is then discussed, so as to understand the channels, if any, through

33 Art 32(1)(a) BRRD.

34 On the doubt over the efficiency and effectiveness of these mechanisms, see supra, note 9.

35 The ideal situation, in which each and every future course of action can be ex ante forecast and disciplined.

36 See, for instance, J Zhou et al, "From Bailout to Bail-in: Mandatory Debt Restructuring of Systemic Financial Institutions" (2012) 3, IMF Staff Discussion Notes.

37 Consistent with the representation hypothesis, see supra, note 26.

38 On the ambiguity in the interpretation and application of the "public interest" principle in recent bank distress cases in Europe, see W-G Ringe, "Bail-In between Liquidity and Solvency", Oxford Legal Studies Research Paper No 33/ 2016, 29. 
which an investor can efficiently allocate control and bargain out of supervisory discretion (see section 2 below).

\section{A brief overview of qualitative requirements ${ }^{39}$}

The BRRD ${ }^{40}$ requires institutions to meet at all times a Minimum Requirement for Own Funds $^{41}$ and Eligible Liabilities ${ }^{42}$ (MREL). Quantitatively, MREL is a tailor-made requirement, while the amount of own funds is statutorily required in the CRR.

Before individually addressing each class of items, three general features should be highlighted. First, for absorbing losses, eligible instruments must provide a genuine contribution of wealth; thus, they cannot be owned by, secured by, funded by or guaranteed by the issuing institution. In fact, if that happened, the losses would be indirectly borne by the issuer itself. Second, eligible instruments are subordinated to all the others and, within eligible instruments, each class of instruments has different seniority. Third, Art 48 BRRD regulates the sequence of subordination, allocating the losses to CET1 holders first, then AT1, T2 and eventually other eligible liabilities, as described in Figure 1.

For explanatory purposes, non-Tier 2 instruments are analysed first, and subsequently Tier 2 and Additional Tier 1. Indeed, to be eligible, junior liabilities must comply with senior liabilities' requirements, and with further requirements specific to the senior class. The analysis covers rules on subordination, maturity of instruments, repayments and distributions. All the requirements are then summarised in Figure 2.

MREL eligible instruments must have a remaining maturity of at least one year. ${ }^{43}$ For instance, a bond whose maturity is 31 January 2025 will be fully counted as MREL eligible until 31 January 2024. Moreover, Art 44(2) BRRD exempts from the application of bail-in some classes of liabilities that are incompatible with the aim of the tool, such as covered deposits. ${ }^{44}$ MREL eligible instruments are not required to comply with specific rules on repayments of principal amount and distribution of interests, while these aspects represent a crucial part of qualitative requirement for more junior capital instruments.

Coming to capital instruments, Tier 2 liabilities must be issued with an initial maturity of at least five years. ${ }^{45}$ The instrument can be redeemed (called, repurchased or repaid) in

\footnotetext{
39 This section focuses partly on Additional Tier 1 instruments and mainly on Tier 2 instruments, as Common Equity Tier 1 instruments fall outside the scope of this research.

40 Art 45 BRRD. In this contribution, MREL is preferred over TLAC as a regulatory standard on which to base the analysis, given its Eurocentric perspective. Nonetheless, the core of the arguments proposed would not vary significantly. On the interrelation between MREL and TLAC, see EBA, "Final Report on MREL" (2016).

41 The aim of MREL requirement is to make the bank able to absorb losses and restore its capital position, allowing it to continuously perform its critical economic functions during and after a crisis. As a first approximation, it consists of the sum of Tier 1 and Tier 2 capital, see Art 71 CRR.

42 Bank liabilities that are not exempted ex Art 44(2) and complies with the requirements of Art 45(4).

43 Art 45(4)(d) BRRD. Note that liabilities with more than seven days to maturity can still be bailed-in in resolution, but they do not count for MREL compliance.

44 For an in-depth analysis of exemptions of Art 44(2), see Tröger, supra, note 8.

45 Arts $63(1)(\mathrm{g})$ and 64 CRR. In the last five years before maturity, the liability is linearly amortised so that only a fraction can be counted as Tier 2 capital. Nonetheless, it is still fully MREL eligible. On the other hand, the full instrument is no longer MREL eligible when it has less than one-year maturity, even though a fraction of the instrument can still be counted as regulatory capital. Such inconsistency does not hamper the overall argument of this contribution.
} 


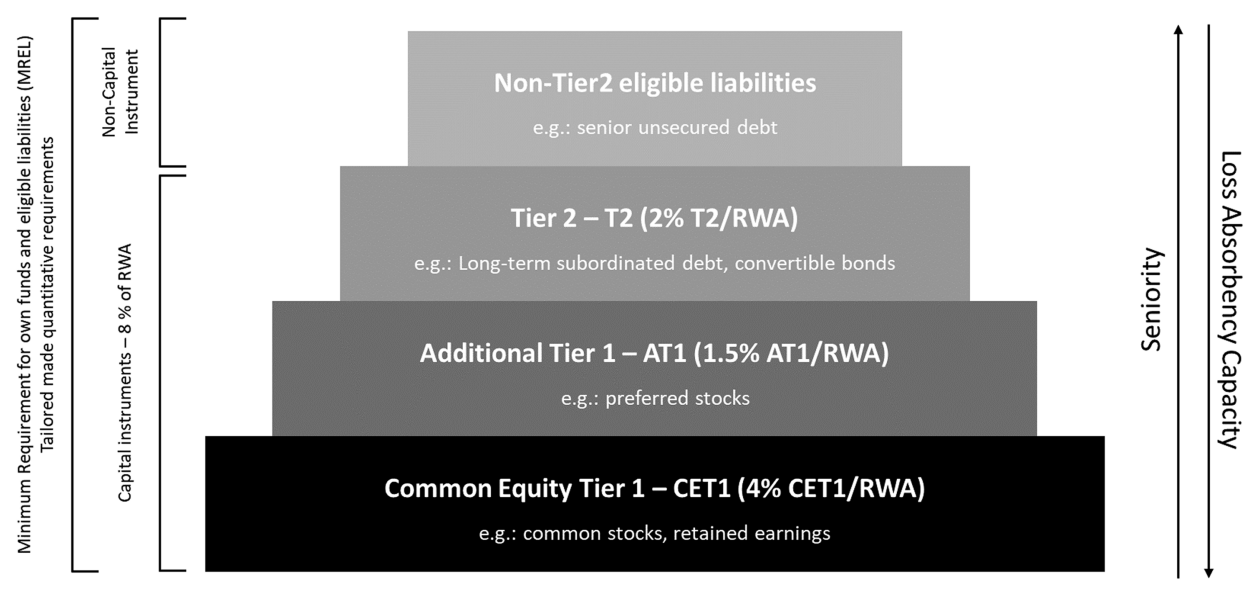

Figure 1. Capital and bail-in eligible liabilities waterfall

advance after five years from the issuance and with prior supervisory approval. ${ }^{46}$ No contractual provisions can provide incentives for early repayment; ${ }^{47}$ and no contractual clause can give the holder the right to accelerate the repayment of interests and the principal amount of the instruments. ${ }^{48}$

Whereas AT1 and T2 items share the provisions governing redeemability, and constraints on contractual clauses, the main difference between the two lies in the perpetuity of AT1 items. Moreover, distributions shall be paid out of distributable items (profits, retained distributable earnings) and the issuer has full discretion in cancelling distributions

Lastly, loss-bearing provisions out of a resolution procedure complement the principle of seniority in resolution. ${ }^{49}$ In fact, according to the CRR framework, AT1 items shall be written down or converted into CET1 when the level of CET1 falls below $5.125 \%$ of RWA, allowing the institution to have new equity when it would be difficult or too expensive to raise. The trigger event for write down or conversion can be higher than the statutory one, if provided in the contract. ${ }^{50}$

\section{Compliance of contractual devices}

This section aims to bring together the framework developed Section II and the analysis of the qualitative requirements discussed in section 1 above. It argues that many of the usual contractual devices are largely unavailable in banking because such devices do not comply with existing regulation.

First of all, it is easy to rule out the possibility of complying with capital and MREL requirements through short-term or secured debt for financial stability purposes. In fact, short-term exposures are prone to run in case of idiosyncratic or systemic turmoil. On the other hand, the stability of financial institutions, as well as the feasibility of resolution

\footnotetext{
Arts 63(1)(j) and 77 CRR.

Art 63(1)(h), (i), (k) CRR.

Art 63(1)(l) CRR.

49 Arts 52(1)(n) and 54 CRR.

50 This specific aspect is crucial: it is extensively discussed in Section IV.
} 


\begin{tabular}{|c|c|c|c|c|c|}
\hline 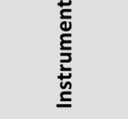 & $\begin{array}{l}\text { Main } \\
\text { Source }\end{array}$ & Maturity & $\begin{array}{l}\text { Loss Absorbency/ } \\
\text { Subordination }\end{array}$ & Distributions & Repayments \\
\hline $\begin{array}{c}\text { Non-Tier } 2 \\
\text { bail-in } \\
\text { eligible }\end{array}$ & $\begin{array}{l}\text { Articles } \\
44,45 \text { and } \\
48 \text { BRRD }\end{array}$ & $\begin{array}{l}\text { At least } 1 \\
\text { reaming year. }\end{array}$ & $\begin{array}{l}\text { BRRD framework } \\
\text { After Tier } 2 \\
\text { instrument. }\end{array}$ & $\begin{array}{l}\text { No specific } \\
\text { requirements }\end{array}$ & No specific requirements \\
\hline Tier 2 & $\begin{array}{l}\text { Articles } \\
62-65 \text { CRR }\end{array}$ & $\begin{array}{l}\text { - At least } 5 y \text { at } \\
\text { issuance; } \\
\text { - callable after } \\
5 y \text { with } \\
\text { supervisory } \\
\text { permission. } \\
\text { - linear } \\
\text { amortization in } \\
\text { the last } 5 y \text {. }\end{array}$ & $\begin{array}{l}\text { BRRD framework } \\
\text { After AT1 } \\
\text { instruments. }\end{array}$ & $\begin{array}{l}\text { No specific } \\
\text { requirements }\end{array}$ & $\begin{array}{l}\text { - no contractual incentives to } \\
\text { redeem or repay in advance; } \\
\text { - call option at sole discretion } \\
\text { of the issuer; } \\
\text { - instruments are callable or } \\
\text { redeemable after } 5 \text { years upon } \\
\text { supervisory approval; } \\
\text { - no contractual indication of } \\
\text { anticipated repurchase or } \\
\text { repayment; } \\
\text { - No contractual provision for } \\
\text { repayment acceleration. }\end{array}$ \\
\hline $\begin{array}{l}\text { Additional } \\
\text { Tier } 1\end{array}$ & $\begin{array}{l}\text { Articles } \\
\text { 51-55 CRR }\end{array}$ & $\begin{array}{l}\text { Perpetual, } \\
\text { callable after } 5 \\
\text { years with } \\
\text { supervisory } \\
\text { permission. }\end{array}$ & $\begin{array}{l}\text { CRR framework } \\
\text { Rank below Tier 2; } \\
\text { Principal write down } \\
\text { or conversion upon a } \\
\text { trigger event; } \\
\text { BRRD framework } \\
\text { After CET1 } \\
\text { instrument. }\end{array}$ & $\begin{array}{l}\text { - Paid out of } \\
\text { distributable } \\
\text { assets } \\
\text { - Full discretion } \\
\text { for the issuer to } \\
\text { cancel } \\
\text { distribution }\end{array}$ & $\begin{array}{l}\text { - no contractual incentives to } \\
\text { redeem or repay in advance; } \\
\text { - call option at sole discretion } \\
\text { of the issuer; } \\
\text { - instruments are callable or } \\
\text { redeemable after } 5 \text { years upon } \\
\text { supervisory approval; } \\
\text { - no contractual indication of } \\
\text { anticipated repurchase or } \\
\text { repayment; } \\
\text { - no contractual provision for } \\
\text { repayment acceleration. }\end{array}$ \\
\hline
\end{tabular}

Figure 2. Outline of the main qualitative requirements for bail-in eligible liabilities

procedures, beg for long-term non-runnable items on which other short-term investors, depositors and the market as a whole can rely. In a similar vein, eligible liabilities need to actually absorb losses. Therefore, secured items are radically incompatible with the aim of capital regulation, and the principles of resolution, as the loss-absorbency capacity would only be fictional, and the losses would still be allocated to the institution.

The situation is more entangled when it comes to covenants. Covenants' salience can be grasped by referring to Patrick Bolton: "In short, the area where the issue of contractual incompleteness perhaps matters most, when it comes to debt contracts, is the design and enforcement of debt covenants". 51

First, for the sake of financial stability and public trust, using a covenant breach as an event of default to force debt renegotiation represents an unavailable option. ${ }^{52}$ In fact, contractually granting the opportunity to force a financial institution into bankruptcy in case of a breach would provide the creditor with disproportionate power, putting her in the position to generate significant negative externalities for the whole economy. Covenants can also have

51 P Bolton, "Corporate Finance, Incomplete Contracts, and Corporate Control" (2013) 30 Journal of Law, Economics and Organisation 64 at 75.

52 This solution is widely employed and desirable in corporate debt. See empirical evidence furnished in G Nini et al, "Creditor Control Rights, Corporate Governance, and Firm Value" (2012) 25(6) Review of Financial Studies 1713. 
other functions, namely to speed up repayment in case of a breach, so to end an exposure that is considered to be too risky and to impose behavioural remedies upon covenant breaches. ${ }^{53}$

As previously described, speeding-up repayment is unavailable for capital instruments, while there are no constraints for non-capital eligible items. One could say that the regulator has extensive control over capital items both through regulatory tools, such as the ban on the acceleration of repayment, and supervisory tools, such as the necessary permission to call items earlier than the original maturity.

Instead, behavioural covenants (eg restriction on payment of dividends) are, in principle, compliant with the requirements of both capital and non-capital items. Nonetheless, it should be noted that covenants are costly to draft and enforce. Therefore, it might well be that, even if available, their costs outweigh the benefits. In fact, banks assets and operations are, by definition, opaque, so monitoring costs are higher than in nonfinancial firms. In addition, there is a set of rules mimicking the possible behavioural covenants that could be imposed: ${ }^{54}$ think, for instance, about the restrictions on dividends provided by Art 141 of the Capital Requirement Directive (CRD IV). ${ }^{55}$ Thus, in comparison with non-financial firms, imposing covenants would be more costly, because of the higher cost of compliant drafting, monitoring and enforcement. On the other hand, benefits, if any, would amount to the marginal increase of mismanagement deterrence that a tailor-made covenant can yield on top of the supervisory rules. ${ }^{56}$ To sum up, consistent with the costly contracting hypothesis, qualitative requirements leave sufficient room for covenants even if complementary rules and the nature of financial institutions shrink the scope for efficient covenants.

Finally, some attention has to be devoted to the hypothesis of statutory bankruptcy and the special ways in which it materialises for banks. Once the bank reaches the point of non-viability, there are two main options: liquidation (gone concern) and resolution (going concern). ${ }^{57}$ For what is of interest here, gone concern options can be neglected, as the procedure of bank liquidation has no governance implication, ie no contingent shift in control. On the contrary, in a going concern scenario, investors can have a potentially relevant governance impact when the resolution authority decides to convert eligible liabilities into shares. ${ }^{58}$

\footnotetext{
53 Restriction on investments (eg mergers), on financing (eg future senior debt issuances) and on dividends, as categorised in Bradley and Roberts, supra, note 20.

54 See Section II about the theory of banking regulation and the representation hypothesis, supra, note 26.

55 Directive 2013/36/EU of the European Parliament and of the Council of 26 June 2013 on access to the activity of credit institutions and the prudential supervision of credit institutions and investment firms [2013] OJ L 176. For a deeper analysis of the governance provisions contained in the CRD IV that might mimic potential covenants, see L Enriques and D Zetzsche, "Quack Corporate Governance, Round III? Bank Board Regulation Under the New European Capital Requirement Directive" (2015) 16 Theoretical Inquiries in Law 211.

56 The risk of redundancy and conflicts for covenants on bail-inable securities and existing regulation has been highlighted also in F Mann et al, "Market Discipline and UK Bank Bondholders" (2017) 57 Bank of England Quarterly Bulletin 26.

57 In the liquidation scenario, the bank is shut down according to national insolvency and the legal entity ceases to exist. In the resolution scenario, the critical functions of the bank continue, as provided by Art 31(2)(a) BRRD, and the distress of the bank is coped with by an administrative procedure employing one or more resolution tools provided in the BRRD. The result can be either full going-concern scenario, where the original legal entity is made viable and continues to operate (eg bail-in tool) or a scenario where the original legal entity ceases to exist (eg bridge institution tool).

58 Using the power provided by Art 63(1)(f) BRRD, while the power to write down provided by Art 63(1)(e) is not considered here, for the reasons discussed above in the case of gone concern solutions.
} 
In fact, some authors have argued that converting debtors into shareholders may influence the incentives of managers towards risk-taking. ${ }^{59}$ Moreover, it is likely that the conversion of other instruments follows the heavy dilution or even the complete writeoff of outstanding shares. ${ }^{60}$ Hence, a radical shift in control would happen. Some preliminary observations are worth discussing.

First, as opposed to clearly defined economic rights, governance characteristics of converted shares are not clearly regulated. Indeed, eligible items ought to be converted into common shares, as preferences in distributions and repayment are not allowed under the subordination requirement of CET $1 .{ }^{61}$ On the contrary, in neither the CRR nor the BRRD is the issue of governance rights of the converted items addressed. ${ }^{62}$

Second, the conversion would happen at the point of non-viability, so that the incentives of new shareholders would not sharply differ from the old ones' in terms of risk shifting and gambling for resurrection. ${ }^{63}$ No rational reasons, indeed, lead us to believe that allegedly risk-averse bondholders are sticking to their risk appetite in the event of conversion. In fact, risk appetite cannot be assumed to be immutable, ${ }^{64}$ but is contingently changing according to the investor's payoffs. ${ }^{65}$

Ultimately, the decision of public authorities over the most desirable course of action to undertake, ie the probability of conversion, remains - in the large part - discretionary.

Nonetheless, contracts might come to hand once again. In fact, it is possible to write contractual clauses for the conversion of eligible liabilities into CET1 items once a preestablished trigger event materialises (contingent convertibles). Therefore, theoretically, investors can bargain out of regulatory discretion.

\section{BARGAINING OUT OF DISCRETION: CONTINGENT CONVERTIBLES}

\section{Rationale and design features}

Contingent convertibles (or Cocos) represent an academic invention that dates back to the early $2000 \mathrm{~s},{ }^{66}$ and became popular in the aftermath of the financial crisis, as they have been deemed be innovative items that could potentially disrupt the discourse on

59 This is the underlying idea in Coffee, supra, note 10.

60 See Recital n 77 BRRD: "Losses should first be absorbed by regulatory capital instruments and should be allocated to shareholders either through the cancellation or transfer of shares or through severe dilution".

61 Differential rights in the magnitude of distributions are allowed in case of shares have limited or no voting rights, as provided by Art 28(4) CRR.

62 According to the CET1 requirements shares can have limited or no voting rights. See supra, note 61.

63 This view is antithetical with the one proposed by some authors, claiming under the assumption that creditors are structurally more risk-averse than shareholders. See, for instance, Coffee, supra, note 10 and Zhou et al, supra, note 36.

64 Here, the assumption on constant preference still holds, and given the risk preference, the appetite toward risk varies according to the specific context. This conservative approach is sufficient for the argument in this paper. Moreover, one could go further and relax the assumption according to which preferences are constant, leaning towards the strand of literature in behavioural economics on context-specific preferences: see A Tversky and I Simonson, "Contextdependent preferences" (1993) 39(10) Management Science 1179.

65 This line of reasoning is reinforced by the fact, under the MiFID II framework, bail-inable securities are classified as a "complex instruments", and it is highly complex for retail investors to buy them: "Guidelines on complex debt instruments and structured deposits" 4 February 2016, ESMA/2015/1787.

66 M Flannery, "No Pain, No Gain? Effecting Market Discipline via 'Reverse Convertible Debentures'” in H Scott (ed), Capital Adequacy Beyond Basel: Banking, Securities, and Insurance (Oxford University Press 2005). The published version is based on a working paper delivered in 2002. 
financial stability. ${ }^{67}$ Cocos consist of financial instruments that are written down or converted into equity when a contractually predetermined event (trigger) occurs, with the immediate consequence of recapitalising and deleveraging a bank that is going towards financial distress. ${ }^{68}$

From a legal perspective, no EU regulation, neither CRR nor BRRD, ${ }^{69}$ provides for a special regulatory regime for contingent convertibles even though they are part of bailinable securities and, usually, of regulatory capital. A sharply different approach has been employed by the Swiss regulator, where Cocos are the only instruments, other than CET1, that count as regulatory capital. Swiss regulation requires large banks to issue Cocos amounting to at least $9 \%$ of RWAs, of which at least two thirds have a trigger point higher than $7 \%$ of capital over RWAs.

In the EU, Cocos count for regulatory capital as long as their characteristics comply with qualitative requirements for specific classes, as discussed in Section III. Hence, they count as AT1 if they are perpetual and distributions are discretionary, or as T2 if they are long-term, or even non-capital bail-in eligible if they have maturity shorter than five years or they embed covenants that are incompatible with capital instruments. Yet, it is clear that issuing non-capital Cocos would make little sense since the bank would need to issue costly instruments twice. Thus, it is reasonable to argue that Cocos are either AT1 or T2, depending on their characteristics, ${ }^{70}$ with the additional constraint that the trigger event of AT1 cannot be lower than $5.125 \%$ of CET1 over RWAs. ${ }^{71}$

Looking closer at the literature on convertible items, it appears clear that "contingent convertible" represents an umbrella concept that comprehends a wide variety of items, whose goal and main characteristics are similar while sharply differing in their design. While a comprehensive survey of various proposed designs cannot be provided here, some crucial aspects ought to be introduced.

First, setting the correct trigger event is crucial for efficient design, this a conundrum that financial economists are busy discussing. Here it is sufficient to emphasise that there are two main policy options: Cocos with high or low triggers. High trigger indicates the fact that the triggering event is relatively far from the point of non-viability, ${ }^{72}$ while low trigger means the opposite. Second, Cocos can contractually provide both for conversion or write down of their principal amount once the event is triggered. ${ }^{73}$ Third, a further variation is to design re-convertible items, ie to contractually establish a second event that, if triggered, converts back the shares into Cocos. The re-conversion can be

\footnotetext{
67 See, among many other, M Flannery, "Stabilizing Large Financial Institutions with Contingent Capital Certificates" (2016) 6 Q J Fianc 1650006.

68 P Bolton and F Samama, "Capital Access Bonds: Contingent Capital with an Option to Convert" (2012) 27 Economic Policy 275 at 278.

69 Art 44(13) and (14) BRRD provides for the possibility to meet MREL with contractual bail-in.

70 Besides, for tax shielding purposes, most likely Cocos issuances take the form of bonds, even if they could - in principle - be preferred stocks.

71 Art 54(1) CRR.

72 The market value of shares represents the crucial variable, as when multiplied by outstanding shares and divided by the assets as indicated by latest available accounting data, they provide a proxy for the market value of banks equity and the level of financial distress.

73 For mutual banks, only the principal write-down option is available, as they do not have common shares to exchange with convertible bonds. Thus, for instance, Rabobank in 2010 issued convertible bonds providing for writing their principal amount down once the event is triggered.
} 
automatic or in the form of an option in favour of the converted shareholders. As Section IV.3 illustrates, the design with a reconversion option has beneficial effects from a corporate governance perspective.

Given the rationale and the design features of Cocos, the following section explores the impact of issuing Cocos on risk-taking incentives.

\section{Cocos and risk-taking}

There is no consensus in the economic literature about the impact of Cocos on risktaking, since there is no generalised view on how to approach the issue, and the outcome is highly dependent on the assumptions of the various models. ${ }^{74}$ The overall effect on risk-taking appetite can be disentangled into three main dimensions.

First, the immediate consequence of converting Cocos into ordinary shares is to deleverage the balance sheet of the bank which, in turn, reduces the incentives for "risk shifting" and "gambling for resurrection" behaviours. It should be noted that this can be a persistent effect only if the bank is, latu sensu, profitable. In fact, if the value of shares keeps decreasing, the beneficial effect of deleveraging will not last.

Second, there is an effect on incentives toward monitoring. In fact, Cocos holders bear losses with relatively high probability, so that their incentives to monitor banks' activities in general, and the trigger event-related issues in particular, increase. ${ }^{75}$

Third, and most relevant for our purposes, there might be "pure" governance effects, ie contractual design of convertible items positively copes with the agency problems among corporate constituencies, providing for ways to assure a return on investment ${ }^{76}$ better aligned with risk-decreasing attitude. In the following paragraphs we discuss the potential for beneficial governance effects and the necessary contractual features for them to materialise.

\section{Governance feature of Cocos design}

The crucial issue in assessing the governance benefits deriving from contingent convertibles rests upon the type of shares Cocos are converted into. ${ }^{77}$ As a first approximation, one can think of two main possibilities: first, converting Cocos into plain ordinary shares that do not differ from the pre-existing ones in the voting and economic rights; second, converting Cocos into different kind of shares with different voting and economic rights.

\footnotetext{
74 Some papers argue for the risk-reduction effect, while some others claim the exact opposite. See, respectively, N Martynova and E Perotti, "Convertible Bonds and Bank Risk-Taking" (2018) J Financ Int 61; and T Berg and C Kaserer, "Does Contingent Capital Induce Excessive Risk-Taking?" (2015) J Financ Int 356.

75 Note that the increase on monitoring incentives may well be suboptimal, because the costs still outweigh the expected benefits or because of the complex and unpredictable legal framework. On the sub-optimality of market discipline through monitoring, see E Avgouleas and J Cullen, "Market Discipline and EU Corporate Governance Reform in the Banking Sector: Merits, Fallacies, and Cognitive Boundaries" (2014) 41(1) Journal of Law and Society 28.

76 See the definition of corporate governance by Shleifer and Vishny, supra, note 17, provided in Section II.

77 For explanatory purposes, this section assumes that the troubled bank has only one class of shares providing one vote to each share. A complex structure with multiple share classes would not hamper the overall argument, even though it could make the shift in control more difficult (for instance in the case of multiple voting shares).
} 
In fact, as discussed above in Section III.2, if the converted shareholders have the same position as the pre-existing ones there is no rational ground for arguing that their risk incentives are going be more risk-averse just because they were bondholders beforehand.

However, as the previous discussion may have clarified, designing financial instruments for banks is all but straightforward and unrestricted, so it is issuing CET1 instruments. Thus, for qualifying as CET1, shares must not be in any way preferred to other CET1 items, either in distributions of dividends or in liquidation. ${ }^{78}$ This hampers, at least in the EU framework, the argument put forward by Coffee about positive governance effects if Cocos are converted into preferred stocks with considerable voting rights. ${ }^{79}$ Within equally subordinated shares, CRR makes it possible to differentiate the quantity of voting and economic rights. In fact, banks, in principle, can issue multiple, restricted or non-voting shares and economic rights can be adjusted accordingly; ie higher economic rights can be attached to shares with fewer or no voting rights. ${ }^{80}$

Given this framework, governance effects arise both before and after conversion. In good times, shareholders are averse to conversion if that means a considerable dilution of their voting or economic rights. ${ }^{81}$ Moreover and most importantly, once the bank runs into financial distress and the conversion happens, Cocos holders are playing an active governance role whose content is highly dependent on the contractual design of converted shares. In fact, if risk appetite is context dependent - so that one cannot rationally expect that Cocos holders will stick to their risk-averse attitude once converted - this is also true for contractual entitlements that vary the context and so the appetite toward risk.

Three possible designs can be considered, to discuss the governance role of converted shareholders.

(1) No voting rights: in this scenario, converted shareholders have no say in the decision-making process of the bank, so their direct governance impact is negligible, whereas the "deleveraging effect" stays the same. It should be noted that higher economic rights, compliant with CET1 requirements, could be attached to non-voting shares so that the ex ante aversion of pre-existing shareholders to conversion can be slightly amplified.

(2) Same voting and economic rights: in this situation, the argument about contextdependent risk appetite applies; hence, converted shareholders have the same risk incentives as the pre-existing ones. Yet, if controlling shareholder extracts detrimental private benefits from control, ${ }^{82}$ the conversion can still have beneficial governance consequences. In fact, if the number of converted shares is big enough to alter the existing control power, converted shareholders can push for more of a shareholder's value-oriented management, for instance substituting the incumbent managers.

\footnotetext{
78 Art 28(1)(h)(i) CRR. This implies that preferred stocks would not count as CET1 but as AT1 instruments.

79 See Coffee, supra, note 10.

80 Art 28(4) CRR.

81 This is also an argument in favor of large conversions that can ex ante threaten shareholders. Moreover, as discussed supra, note 77, if the banks have a complex dual class structure the ex ante effect could be weakened. An immediate follow-up of this argument is that high-trigger Cocos amplify the aversion to conversion.

82 On private benefits of control and the cases in which it is harmful to firm's value, see A Pacces, Rethinking Corporate Governance: The Law and Economics of Control Powers (Routledge 2013).
} 
Moreover, the conversion scenario in this situation would amplify the ex ante averseness towards conversion of controlling shareholders that may opt for limiting the private benefit extracted from the bank. Yet, absent any regulatory requirement to issue Cocos, a simpler solution is not to issue them in the first place.

Even out of the latter scenario, the incentive parallelism can be modified by providing converted shareholders with an option to reconvert to Cocos once a second trigger event is breached. So, in case of a high-trigger Cocos that converts into shares, once the turmoil is overcome, the converted shareholders have the opportunity to opt for reconversion to a relatively safer asset, undercutting the shift toward larger risk appetite. This would elicit the risk-preference of converted shareholders, so that the genuinely risk-averse ones will push for a more cautious approach to get out of distress and reconvert to bonds. Thus, if the trigger is high enough not to provide "gambling for resurrection" incentives and the number of converted shares is big enough to impact on the control of the bank significantly, the reconversion option can be a powerful tool.

(3) Limited voting rights: it is relatively common for companies to issue classes of shares whose voting rights are limited to specific issues (usually strategic decision, such as mergers) or contingent on some event (eg dividends are not distributed for two years in a row). In our context, limited voting rights seem more likely to occur. In such a scenario, most of the arguments proposed for (unrestricted) voting shares are applicable, including the beneficial effect of an option for reconversion.

What sharply differs from the latter design is that restricted voting shares are not apt to perform a shift in control, since they do not usually provide for voting rights on the election of the board. Therefore, the magnitude of the beneficial impact is more limited than for the previous design, especially with regard to limiting the private benefit of control. Finally, limited voting shares can provide enhanced economic rights, which ex ante increase the aversion towards conversion of pre-existing shareholders.

While it is impossible to provide a comprehensive assessment of each and every possible design feature, the three mentioned above are, arguably, the paradigms of general application. Indeed, in addition to the main designs discussed, one can think of a wide variety of more "exotic" variations, for instance converting Cocos into a class of shares that have the specific right to appoint one or more directors or, again, the case for multiple voting rights shares. However, these cases are highly jurisdiction-dependent, and it is not possible to analyse all of them. In fact, it is not only capital requirements that impose qualitative restrictions on shares, but also national corporate laws. So, for instance, it is relatively easy to issue multiple voting shares in Anglo-Saxon jurisdictions, but that is not the case in civil law oriented ones, where the principle of "one-share-onevote" still consistently applies. The same argument goes for the specific rights to elect directors: it could be relatively simple in Italy, where the slate voting procedure for board election represents a well-established legal tool, but it may turn out to be virtually impossible in Germany, where the co-determination principle makes the composition of the board a particularly delicate equilibrium.

To sum up, the contractual design of Cocos matters for corporate governance. Design features that differentiate the incentives of pre-existing and converted shareholders are potentially able to decrease the overall risk appetite of the bank as long as the trigger event of conversion is set relatively high and the number of converted shares is 
significant enough to impact on corporate decision-making. This markedly differentiates Cocos from other bail-inable securities, as their design, given the current regulatory framework, is unfit to discipline the risk-taking behaviours of managers.

\section{CONCLUding REMARKS}

This article discusses the trade-off between financial stability and market discipline through the lens of contractual possibilities in designing bail-inable securities. Financial stability considerations prevail both in the pre-crisis and post-crisis regulatory framework, insofar as there are no compelling arguments to strongly favour market discipline imposed through contract over financial stability.

Given the current regulatory framework, this paper has explored the space left to investors to have an impact on banks' stability through contractual arrangements, mainly following the literature on contingent allocation of control and looking at financial regulation as constraints to contractual freedom. Moreover, it tackles the subject of the governance consequences of issuing contingent convertible instruments, given the EU regulatory framework, which, to the best of the author's knowledge, was hitherto an unexplored field in the European literature.

Traditional contractual devices are typically unavailable, either because of capital regulation or the recovery and resolution framework. Moreover, even when contractual devices are compliant with existent regulation, the room for actually impacting on bankers' behaviour is limited, not least because of the risk of redundancy with other pieces of legislation.

The situation changes in the case of contingent convertible instruments. From the perspective of financial stability, Cocos represent a powerful buffer, especially if the trigger event is far from the point of non-viability. Moreover, the available contractual characterises of Cocos, if properly designed, can have an impact on the ex ante and ex post risk appetites of banks that decide to issue them. In particular, the crucial design features consist of voting rights, economic rights, and reconversion options, so as to diversify the incentives of original shareholders from the ones of Cocos holders. 